\title{
Penanganan resesi gingiva Miller klas I-II menggunakan platelet-rich fibrin dan subepithelial connective tissue graft
} Treating gingivalrecessionMiller's class I-II using platelet-rich fibrin and subepithelial connective tissue graft

\author{
${ }^{1}$ Mientje Tengkawan, ${ }^{2}$ Sri Oktawati, ${ }^{2}$ Arni Irawaty Djais, ${ }^{3}$ Burhanuddin DP \\ ${ }^{1}$ PPDGS Periodonsia \\ ${ }^{2}$ Bagian Periodonsia \\ ${ }^{3}$ Bagian Ilmu Kesehatan Gigi Masyarakat \\ Fakultas Kedokteran Gigi, Universitas Hasanuddin \\ Makassar, Indonesia
}

\begin{abstract}
Platelet-rich fibrin $(P R F)$ is the generation of platelet concentrates containing growth factors, which play a role in the process of healing and tissue regeneration. This study aimed to compare the effects of using of PRF with subepithelial connective tissue graft (SCTG) as a treatment to gingival recession Miller Class I-II. Nine patients with bilateral gingival recession, as the subjects have two recessions. One side was treated with coronally advanced flap $(C A F)+S C T G$, while the other side was treated with $C A F+P R F$. The length of the recession is measured and calculated as the percentage of root closure before and after surgery (10 and 30 days). The results showed that there were significant differences in the average length of recessions between PRF and SCTG before and after the action on day 10 and day 30 ( $p<0.05)$. Closing percentage of gingival recession 10 days after SCTG treatment was 7 (77.8\%) had experienced completely closing; while the PRF, only 6 (66.7\%); $p>0.05$. Whereas on day $30^{\text {th }}$, after SCTG treatment, all subjects had undergone a recession closing perfectly, while the PRF group only 66,7\% recession that have closing completely $(p=0.05)$. It was concluded that the $C A F+S C T G$ provide maximum results compared with $C A F+P R F$ in treating gingival recession Miller Class I-II.
\end{abstract}

Keywords: subepithelial connective tissue graft, platelet-rich fibrin, coronally advanced flap

\begin{abstract}
ABSTRAK
Platelet-rich fibrin (PRF) merupakan generasi trombosit konsentrat yang mengandung growth factors, yang berperan dalam proses penyembuhan dan regenerasi jaringan. Penelitian ini dimaksudkan untuk membandingkan efek penggunaan PRF dengan subepithelial connective tissue graft (SCTG) untuk menangani resesi gingiva Miller klas I-II. Sembilan penderita resesi gingiva bilateral, masing-masing memiliki 2 resesi menjadi subjek. Satu sisi dirawat dengan coronally advanced flap (CAF)+SCTG, sedangkan sisi yang lain dirawat dengan CAF+PRF. Panjang resesi diukur dan dihitung persentase penutupan akar sebelum dan setelah pembedahan (10 dan 30 hari). Hasilnya, terdapat perbedaan bermakna rata-rata panjang resesi antara PRF dan SCTG sebelum dan sesudah tindakan pada hari ke-10 dan hari ke-30 $(\mathrm{p}<0,05)$. Persentase penutupan resesi gingiva pada 10 hari setelah tindakan SCTG, $7(77,8 \%)$ telah mengalami penutupan resesi secara sempurna; sedangkan pada tindakan PRF, hanya $6(66,7 \%)$; p>0,05. Sedangkan pada hari ke30, setelah tindakan SCTG, semuanya telah mengalami penutupan resesi secara sempurna; dibandingkan hanya $66.7 \%$ kelompok PRF yang menutup secara sempurna $(\mathrm{p}=0,05)$. Disimpulkan bahwa $\mathrm{CAF}+\mathrm{SCTG}$ memberikan hasil yang lebih maksimal dibandingkan dengan $\mathrm{CAF}+\mathrm{PRF}$ untuk menangani resesi gingiva Miller klas I-II.
\end{abstract}

Kata kunci: subepithelial connective tissue graft, platelet- rich fibrin, coronally advanced flap

Koresponden: Mientje Tengkawan. E-mail: $\mathrm{m} \_$tengkawan@yahoo.com

\section{PENDAHULUAN}

Resesi gingiva merupakan masalah mukogingiva yang mempunyai manifestasi klinis yang sangat luas, yang dapat mempengaruhi estetika dan kesehatan gigi penderita. Berbagai macam bahan dan prosedur bedah plastik periodontal telah banyak dipaparkan dalamberbagai pustaka untuk memperbaiki masalah mukogingiva dan untuk menutupi permukaan akar yang sedang terbuka. Akan tetapi, setiap teknik dan bahan kedokteran gigi yang digunakan dalam bedah plastik periodontal memiliki keterbatasan, dengan tingkat keberhasilan yang berbeda-beda.
Keberhasilan teknik free gingival graft (FGG) dalam menutup akar gigi yang terbuka berkisar 53$85 \%$. Sedangkan teknik subepithelial connective tissue graft (SCTG) memberikan hasil yang lebih memuaskan, yaitu 80,0-98,4\%. ${ }^{1}$ Teknik ini paling sering digunakan karena tingkat keberhasilannya menutup akar yang resesi lima kali lipat dibandingkan dengan teknik FGG, sehingga SCTG juga disebut sebagai gold standard dalam penanganan resesi gingiva. $^{2}$

Salah satu bentuk teknik pedicle flap, coronally advanced flap (CAF), ${ }^{3}$ dapat menutup permukaan 
akar tanpa pengambilan graft dari sisi lain, akan tetapi data menunjukkan bahwa penggunaan CAF secara tunggal untuk menutup area resesi tidakstabil dalam jangka waktu yang lama karena dapat terjadi resesi ulang. ${ }^{1}$ PotensiCAF untuk menutupi akar yang resesi tergantung pada jaringan keratinisasi dalam ukuran apikokoronal yang merupakan parameter penting dalam mencegah resesi ulang terjadi. ${ }^{1,2,4}$ Kombinasi teknik CAF+SCTG memberikan hasil yang sangat memuaskan. ${ }^{2}$

Saat ini, kemajuan dalam bidang ilmu sel dan biologi molekuler telah memberikan kontribusiuntuk peningkatan penyembuhan luka. Data klinis serta histologis mengungkapkan bahwa regenerasi jaringan melalui konsep terapi konsentrat platelet menjadi media penyembuhan dan regenerasi jaringan lunak di bidang periodontologi dan implan dental. ${ }^{4-6}$

Platelet-rich fibrin (PRF) merupakan generasi trombositkonsentratyang pengolahannya sederhana, yang memberi efek peningkatan penyembuhan dan regenerasi. Choukroundkk yang mengembangkannya pertama kali di Prancis yang digunakan khusus dalam bedah mulut dan maksilofasial. ${ }^{1,7}$ Teknik persiapan PRF lebih sederhana, tidak membutuhkan trombin anticoagulant sapi seperti pada platelet rich plasma (PRP), sehingga sediaan inibenar-benar autologous. ${ }^{1,-9}$

Penelitian klinis ini dilakukan untuk mengevaluasi penggunaan PRF untuk perawatan resesi gingiva Miller klas I-II yang dibandingkan dengan SCTG melalui teknik CAF, serta untuk mengetahui dampak PRF pada penyembuhan jaringan lunak.

\section{BAHAN DAN METODE}

Penelitian ini melibatkan 3 pria dan 6 wanita berumur 31-58 tahun. Subjek penelitian memenuhi kriteria inklusi, yaitu memiliki resesi gingiva Miller klas I-II pada 2 sisi rahang (kiri dan kanan), pada rahang atas atau rahang bawah mulai dari gigi insisivus sampai premolar dengan lebar attached gingiva $\geq 3 \mathrm{~mm}$, tidak merokok, tidak menderita penyakit periodontal, kedalaman poket tidak lebih dari $3 \mathrm{~mm}$, tidak mempunyai karies yang dalam maupun tambalan pada sisi labial/bukal di akar gigi yang akan diberi tindakan, tidak menderita kelainan bekuan darah maupun penyakit sistemik lainnya, dan tidak sedang mengkonsumsi obat antikoagulan yang menyebabkan pembesaran gingiva, dan tidak menolak menandatangani informed consent. Sebelum tindakan bedah, setiap pasien diberi terapi periodontal awal.

Penelitian ini merupakan uji klinis dengan rancangan matching pretest-posttest control group. Salah satu sisi dikategorikan sebagai kelompok A, sedang sisi lain sebagai kelompok B yang dipilih secara acak. Kelompok A diberi perlakuan berupa tindakan operasi teknik CAF+SCTG, sedangkan kelompok $\mathrm{B}$ diberi perlakuan berupa teknik $\mathrm{CAF}+$ PRF.Pengukuran panjang resesi dilakukan sebelum tindakan, serta 10 hari dan 30 hari setelah tindakan pembedahan.

Penelitian dilakukan di Rumah Sakit Gigi Mulut Fakultas Kedokteran Gigi Universitas Hasanuddin dimulai bulan Februari 2012, berlangsung selama satutahun; dan telah disetujui oleh Komite Penelitian Kesehatan Universitas Hasanuddin (No.1017/H4.8.4.5. 31/PP36-KOMETIK/2013).

Prosedur pembedahan diawali dengan anestesi lokal pada kedua kelompok. Pada kelompok A, insisi intrasulkus dilakukan pada permukaan labial/bukal gigi yang akan dirawat dengan menggunakan pisau nomor 15; dilanjutkan dengan insisi horisontal pada interproksimal kedua sisi pada gigi resesi tersebut. Selanjutnya dilakukan 2 insisi vertikal divergen hinggadi bawah mucogingivaljunction dengan desain full-thickness flap. Dengan elevator, flap diangkat (gambar 1), dan dilakukan root planning pada akar gigi yang mengalami resesi, kemudian dioleskan asam sitrat PH $1(40 \%)$ selama lima menit lalu dibilas. ${ }^{2}$ Flap kemudian dibuat underlying untuk mencegah tension bila flap dikembalikan pada posisinya. Hal yang sama dilakukan pula pada kelompok B.

\section{Protokol pengambilan SCTG}

Insisi horisontal dilakukan pada daerah palatal 2-3 $\mathrm{mm}$ di bawah kedalaman sulkus, $90^{\circ} \mathrm{ke}$ arah tulang, mulai dari sisi mesial molar pertama ke sisi distal kaninus. Arahkan blade sejajar sepanjang sumbu

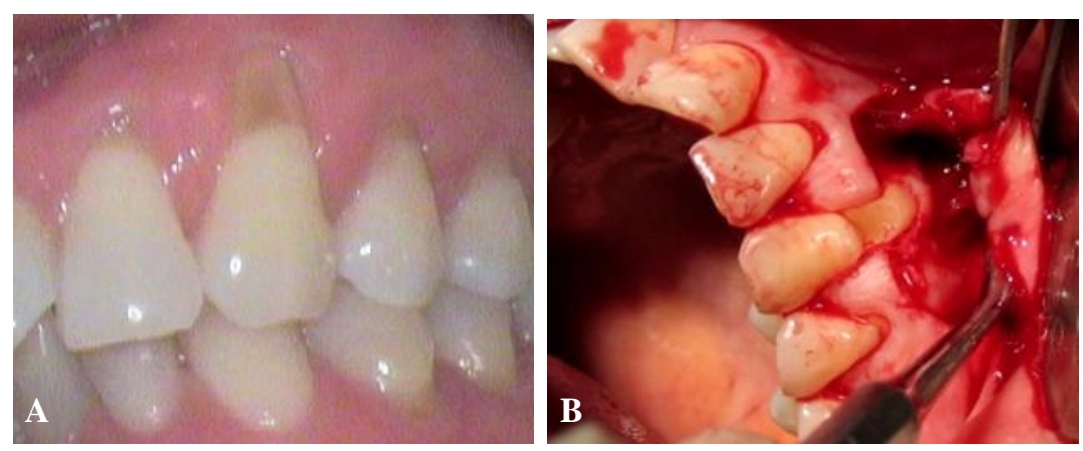

Gambar 1A Gigi 23 mengalami resesi $5 \mathrm{~mm}$, B pembukaan flap 
gigi dan potong $1 / 2$ kedalamannya, lalu gerakkan bladeke arah dalam hingga menyentuh tulang palatal untukmembuat potongan pemisahan posterior bagian dalam dan pemisahan apikal.Selanjutnyapemisahan bagian anterior (gambar 2A), dengan menggunakan elevator menekan hingga menyentuh periosteum, SCTGdilepas (gambar2B), ${ }^{2,4}$ tempatkan graft tersebut pada permukaan resesi akar yang telah dipersiapkan, kemudian dilakukan penjahitan (gambar 2C). Flap kemudiandikembalikan dan dijahit. Area palatal atau donordijahit dengan teknik simple interrupted. ${ }^{2,4}$ Luka ditutup dengan periodontal dressing. Setelah hari ke-10 hari, jahitan dilepas, panjang resesi diukur. Pengukuran dilakukan lagi pada hari ke-30 (gambar $3)$.

\section{Protokol pengambilan PRF}

Darah vena sebanyak $9 \mathrm{cc}$ diambil, dimasukkan ke dalam tabung tanpa antikoagulan, disentrifugasi $2700 \mathrm{rpm}$ selama 12 menit. Setelah itu tampak 3 lapisan, yaitu lapisan atas berisi PRP, lapisan tengah berisi PRF, dan lapisan bawah berisi endapan sel darah merah. Lapisan PRF diambil dengan cara menggunting perbatasan PRF dengan sel darah merah (gambar 4A), lalu segera ditempatkan di permukaan akar yang telah dipersiapkan, dan dijahit (gambar 4B). Flap kemudian dikembalikan dan dijahit, lalu luka ditutup dengan periodontal dressing. Panjang resesi diukur pada hari ke-10 dan 30 (gambar 4C).

\section{HASIL}

Dari keseluruhan sampel, tampak telah terjadi pengurangan panjang resesi gingiva pada kedua kelompok pada hari ke-10 maupun hari ke-30 setelah tindakan (tabel 1). Pada kelompok SCTG, panjang resesi gingiva dari $3,89 \mathrm{~mm}$ menjadi $0,22 \mathrm{~mm}$ pada hari ke-10 dan 0,00 mm pada hari ke-30. Hasil uji Wilcoxon menunjukkan adanya perubahan bermakna $(\mathrm{p}<0,05)$, baik pada hari ke-10 maupun hari ke-30. Hasil yang hampir sama juga terjadi pada kelompok

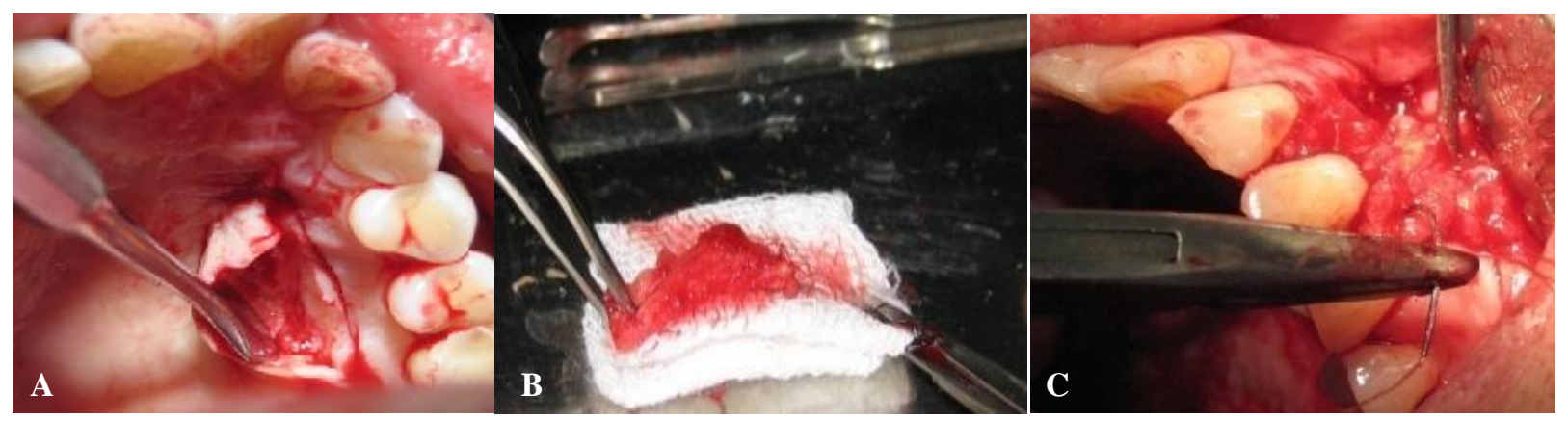

Gambar 2A Insisi palatal untuk pengambilan SCTG, B SCTG yang terambil, C SCTG ditempatkan pada resipien

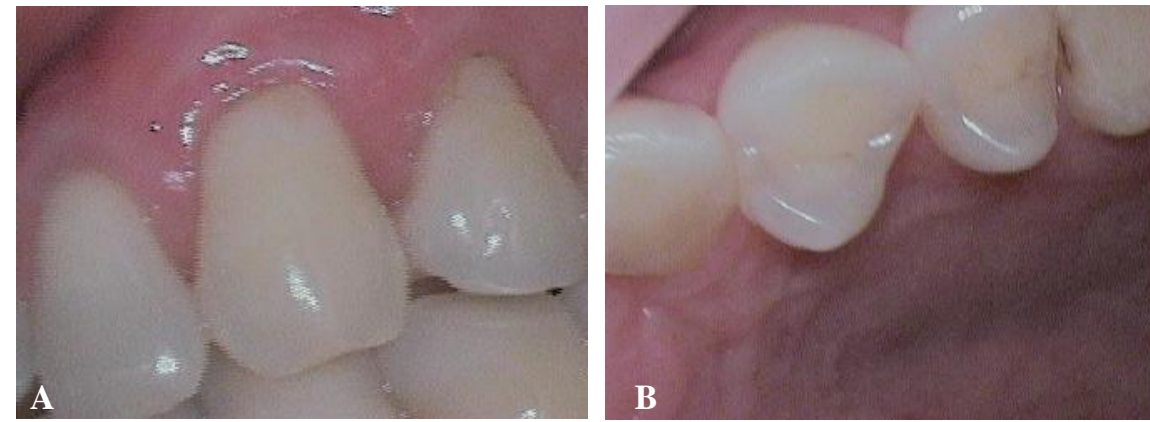

Gambar 3A Area labial 30 hari setelah pembedahan, B area palatal 30 hari setelah pembedahan

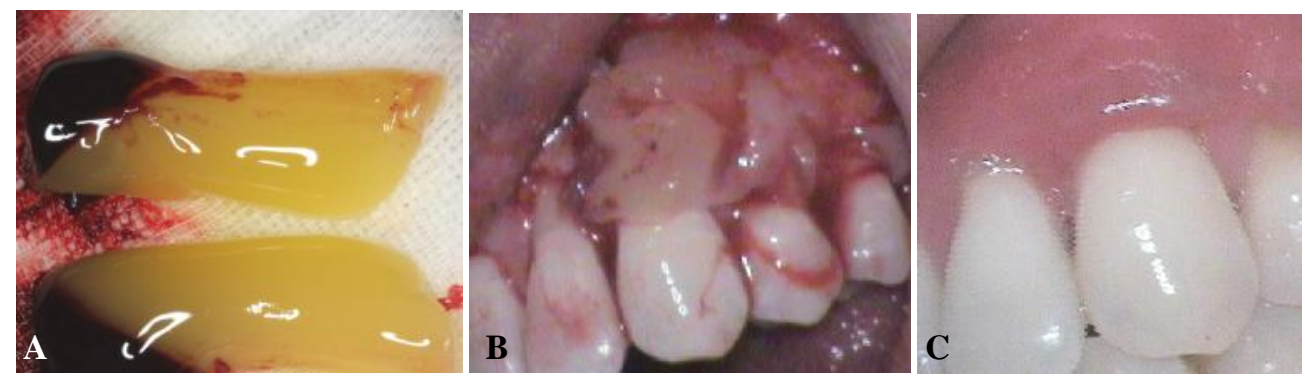

Gambar 4A Platelet-rich fibrin hasil sentrifusi darah, B PRF ditempatkan pada resipien, dan C tiga puluh hari setelah tindakan 
PRF; panjang resesi gingiva pada awalnya $3,33 \mathrm{~mm}$ menjadi 0,56 pada hari ke-10 dan hari ke-30, karena tetap belum menutup sempurna.

Dari grafik 1 nampak perbedaan perkembangan perubahan panjang resesi gingiva antara kelompok penanganan resesi gingiva dengan teknik PRF+SCTG. Walaupun rata-rata panjang resesi gingiva sebelum tindakan pada kelompok SCTG lebih besar daripada kelompok PRF, tetapi pada hari ke-10 pasca tindakan penanganan, rata-rata panjang resesi gingiva pada kelompok SCTG lebih kecil daripada kelompok PRF. Hal ini berarti perkembangan mengecilnya resesi gingiva pada penanganan resesi dengan teknik SCTG lebih cepat daripada teknik PRF dalam rentang 10 hari setelah operasi; ditandai dengan grafik yang lebih curam. Perkembangan mengecilnya resesi gingiva, menurun meskipun landai setelah hari ke30 padakelompok SCTG.Pada kelompokPRF tidak terlihat perubahan, ditandai dengan garis mendatar. Akan tetapi, jika penilaian keberhasilan didasarkan pada sempurnanya penutupan resesi gingiva, bukan perubahan panjang resesi gingiva, maka analisisnya tampak pada tabel 2 untuk perubahan pada hari ke10 dan tabel 3 untuk perubahan hari ke-30.

Tabel 1 Deskripsi panjang resesi gingiva kedua kelompok tindakan pada setiap pengamatan

\begin{tabular}{ccc}
\hline \multirow{2}{*}{ Pengamatan } & \multicolumn{2}{c}{ Panjang resesi gingiva $(\mathrm{mm}):$ minimal-maksimal $($ mean \pm SD $)$} \\
\cline { 2 - 3 } & Kelompok A: SCTG $(\mathrm{n}=9)$ & Kelompok B: PRF $(\mathrm{n}=9)$ \\
\hline Awal & $3,0-5,0(3,89 \pm 0,78)^{\mathrm{a}}$ & $2,0-4,0(3,33 \pm 0,71)^{\mathrm{a}}$ \\
Hari ke-10 & $0,0-1,0(0,22 \pm 0,44)^{\mathrm{b}}$ & $0,0-2,0(0,56 \pm 0,88)^{\mathrm{b}}$ \\
Hari ke-30 & $0,0-0,0(0,00 \pm 0,00)^{\mathrm{b}}$ & $0,0-2,0(0,56 \pm 0,88)^{\mathrm{b}}$ \\
\hline
\end{tabular}

Superscript yang sama pada kolom yang sama berarti hasil uji Wilcoxon tidak berbeda bermakna $(\mathrm{p}>0,05)$, bila berbeda berarti hasil uji Wilcoxon berbeda bermakna $(\mathrm{p}<0,05)$. Superscript yang sama pada baris yang sama berarti hasil uji Mann Whitney tidak berbeda bermakna ( $>>0,05)$, bila berbeda berarti hasil uji Mann Whitney berbeda bermakna $(\mathrm{p}<0,05)$.

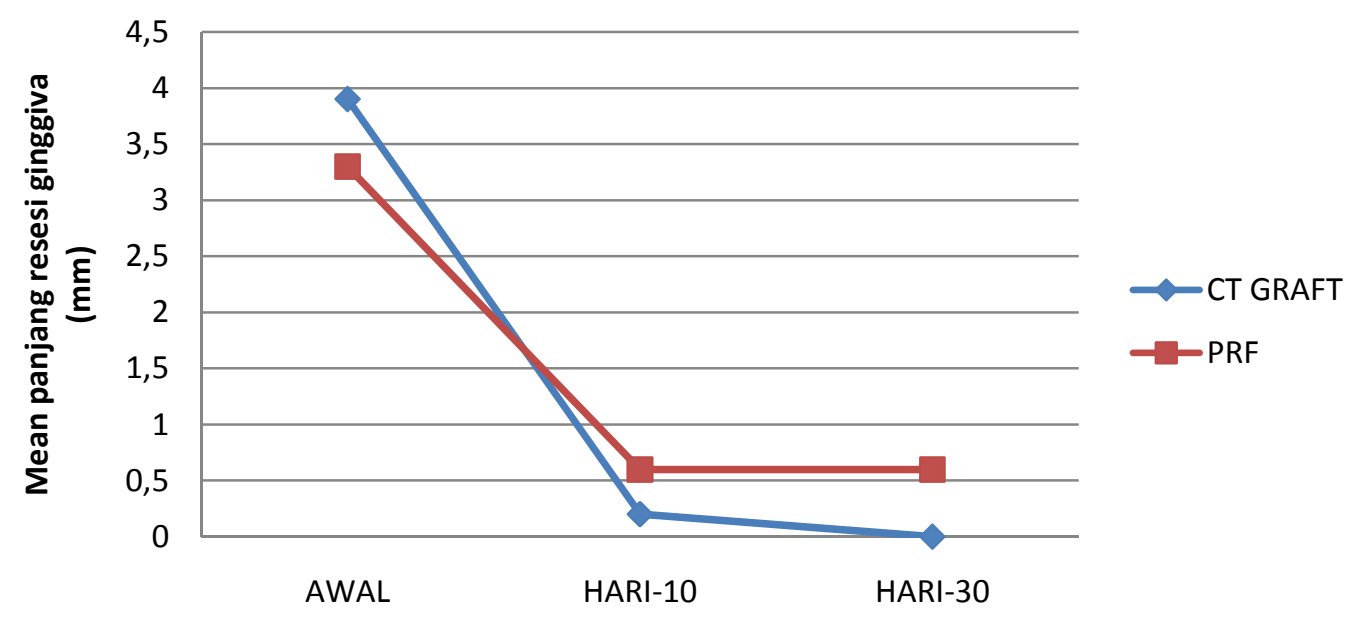

Gambar 1 Grafik garis perbandingan perkembangan perubahan panjang resesi gingiva antara teknik penanganan PRF dan SCTG pada resesi gingiva Miller klas I-II

Tabel 2 Perbedaan distribusi penutupan sempurna resesi gingiva pada hari ke-10 setelah tindakan antara kelompok SCTG dan PRF

\begin{tabular}{cccc}
\hline \multirow{2}{*}{ Kelompok } & \multicolumn{2}{c}{ Penutupan Resesi Gingiva } & \multirow{2}{*}{$\mathrm{p}$} \\
\cline { 2 - 3 } & Sempurna $(\mathrm{n}=13)$ & Tidak sempurna $(\mathrm{n}=5)$ & \multirow{2}{*}{$0,310^{*}$} \\
SCTG $(\mathrm{n}=9)$ & $7(77,8 \%)$ & $2(22,2 \%)$ & \\
PRF $(\mathrm{n}=9)$ & $6(66,7 \%)$ & $3(33,3 \%)$ &
\end{tabular}

"Uji Fisher's exact

Tabel 3 Perbedaan distribusi penutupan sempurna resesi gingiva pada hari ke-30 setelah tindakan antara kelompok SCTG dan PRF

\begin{tabular}{cccc}
\hline \multirow{2}{*}{ Kelompok } & \multicolumn{2}{c}{ Penutupan Resesi Gingiva } & \multirow{2}{*}{$\mathrm{p}$} \\
\cline { 2 - 3 } & Sempurna $(\mathrm{n}=15)$ & Tidak sempurna $(\mathrm{n}=3)$ & \multirow{2}{*}{$0,05^{*}$} \\
\hline SCTG $(\mathrm{n}=9)$ & $9(100,0 \%)$ & $0(0,0 \%)$ & \\
PRF $(\mathrm{n}=9)$ & $6(66,7 \%)$ & $3(33,3 \%)$ & \\
\hline
\end{tabular}

"Uji Fisher's exact 
Hasil pengamatan padahari ke-10 menunjukkan bahwa 7 diantara 9 gigi $(77,8 \%)$ yang memperoleh tindakan SCTG, resesi gingivanya telah menutup sempurna. Sedangkan pada kelompok PRF, ada 6 diantara9 gigi (66,7\%) telah menutup sempurna. Hasil uji Fisher's exact menunjukkan tidak ada perbedaan bermakna $(p>0,05)$ antara kedua kelompok tindakan. Hasil pengamatan pada hari ke-30, menunjukkan bahwa semua gigi kelompok SCTG telah menutup sempurna, sedangkan pada kelompok PRF tidak terjadi perubahan. Resesi gingiva yang tidak menutup sempurna pada hari ke-10 pada kelompok PRF tetap tidak menutup sempurna pada hari ke-30. Hasil uji Fisher's exact menunjukkan perbedaan bermakna $(\mathrm{p}<0,05)$.

\section{PEMBAHASAN}

Tujuan utama perawatan periodontal adalah mendapatkanregenerasi yang sempurna dari jaringan periodontal.Untuk mencapai keberhasilan maksimal dalam perawatan resesi gingiva, perlu diidentifikasi penyebab resesi dan menghilangkan penyebabnya.

Dalam penelitian ini penggunaan teknik CAF yang dikombinasikan dengan SCTG dalam usaha menutup area resesi gingiva, menunjukkan hasil yang signifikan menutup secara sempurnapada hari ke-30. Hal tersebutmenunjukkan adanya tingkat regenerasi jaringan yang memadai pada permukaan akar gigi. Menurut Diebart dan Mamdouh, ${ }^{2}$ teknik SCTG disamping memberikan dukungan terhadap tingkat regenerasi jaringan, juga memberikan pesan genetik untuk epitel di atasnya menjadi terkeratinisasi. ${ }^{8}$ SCTG ini diambil dari sisi palatal yang merupakan mukosa terkeratinisasidan mempunyai vaskularisasi yang tinggi, sehingga dapat bertahan pada permukaan akar yang avaskuler dan dapat merangsang epitel di atasnya terkeratinisasi. ${ }^{2}$ Jahnke dkk melaporkan bahwa tingkat keberhasilan SCTG mencapai 5 kali lipat lebih besar dibanding teknikfree gingival graft dalam menutup permukaan resesi akarhingga $100 \%{ }^{2}$ Sementara Hirsch dkk dalam studinya selama 2 tahun terhadap 101 pasien resesi gingiva yang terlokalisasi melaporkan bahwa penutupan akar menggunakan subpedicle acellular dermal matrix allografts atau dengan SCTG adalah prosedur yang menjanjikan karena disamping memberi hasil yang stabil selama 2 tahun pasca bedah, juga nampak ada penambahan gingiva berkeratin dan attached gingiva. ${ }^{10}$

Sedangkan pada penelitian ini,tindakan operasi
$\mathrm{CAF}+\mathrm{PRF}$ juga menunjukkan adanya perubahan penutupan resesi, yang berarti ada faktor regenerasi jaringan pada membran PRF; meskipun 3 dari 9 sampel yang belum menutup secara sempurna. Hal ini mungkin disebabkan adanya faktoriatrogenik atau keteledoran dari pasien dalam menjaga kebersihan atau adanya trauma, misalnya menyikat gigi secara keras pada daerah bekas operasi. Meskipun demikian, panjang resesi dari ketiga sampel tersebut nampak berkurang; setidaknya berkurang hingga 1-3 mm. Hal tersebut menunjukkan adanya potensi regenerasi jaringan yang mungkin karena adanya faktor-faktor pertumbuhan utama yang masuk dalam membran PRF, antara lain PDGF, VEGF, dan TGF, yang secara perlahan meningkatkan potensi regenerasi. Kepadatan serat fibrin tersebut merangsang pembentukan neoangiogenesis secara cepat dan struktur dari fibrin network sebagai kuncielemen dari PRF dalam proses penyembuhan. ${ }^{11,12-16}$ Selain itu juga nampak proses penyembuhan yang lebih cepat dan tidak adanya rasa nyeri dibanding kelompok SCTG. Cheung dan Griffin yang dikutip oleh Sato melaporkan bahwa proses penyembuhan pada teknik PRF lebih cepat dan lebih bagus terutama pada minggu pertama dan kedua pasca pembedahan. Keberhasilan ini berkaitan dengan munculnya serat-serat fibrin 100 kali lebih banyak dari normal di dalam membran PRF. ${ }^{12}$

Jankovic dkk melaporkan, keberhasilan PRF dalam penutupan akar secara sempurna setelah 6 bulan pasca pembedahan sebesar $75-85 \% .{ }^{13}$ Sebagaimana ditemukan pada riset ini, penutupan resesi gingiva telah terjadipada hari-10 pasca pembedahan, bahkan penutupan resesi secara sempurna sebesar $66,7 \%$.

Berdasarkan hasil dan pembahasan sebelumnya, disimpulkan bahwa tingkat keberhasilan SCTG lebih baik dari pada PRF. Meskipun demikian, PRF dapat dipertimbangkan sebagai biomaterial baru dalam penanganan resesi gingival karena penyediaannya mudah, tidak melibatkan donor seperti pada SCTG, yang melibatkan pembedahan 2 lokasi sehingga menimbulkan ketidaknyamanan pasca pembedahan. Proses penyembuhan teknik PRF lebih cepat dan implikasi klinis nyeri pasca pembedahan minimal.

Kecenderungan positif pemakaian teknik PRF hendaknya dievaluasi dalam penelitian lanjut yang melibatkan jumlah subjek yang lebih banyak. Pada penelitian ini tidak dievaluasi secara histologis oleh karena itu efek PRF dalam kapasitas regeneratif secara menyeluruh masih perlu diteliti lebih lanjut.

\section{DAFTAR PUSTAKA}

1. Jankovic S, Zoran A, Iva M, Bozidar D. The coronally advanced flap in combination with platelet-rich fibrin (PRF) and enamel matrix derivative in the treatment of gingival recession: A comparative study. Eur J Esthet Dent 2010; 5(3).

2. Dibart S, Mamdouh K. Subepithelial connective tissue graft. Pract Periodont Plast Surg 2006; 6: 31-3. 
3. Cortellini P, Tonetti M, Baldi C, Francetti L, Rasperini G, Rotundo R, dkk. Does placement of a connective tissue graft improve the outcomes of coronally advanced flap for coverage of single gingival recessions in upper anterior teeth? A multi-centre, randomized, double blind, clinical trial. J Clin Periodontol 2009; 36: 68-79. doi: 10.1111/j. 1600-051X.2008.01346.x.

4. Eley BM, Soory M, Manson JD. Mucogingival problems and their treatment. In: Periodontics $6^{\text {th }}$ Ed. Elsevier, 2010; 21: 325-41.

5. Dibart S, Thomas D, editors. Practical periodontal diagnosis and treatment planning. Iowa: Blackwell Publishing; 2010.

6. Bornstein MM, Thomas VA, Dieter DB. Properties of barrier membranes. Buser D, ed. 20 Years of Guided Bone Regeneration in Implant Dentistry. Hanover Park: Quinstessence Publishing Co Inc; 2009. 47-66.

7. David M. Dohan E, Pierre D, de Peppo GM, Del Corso M, Charrieret JB, al. Choukroun's platelet-rich fibrin (PRF) stimulates in vitro proliferation and differentiation of human oral bone mesenchymal stem cell in a dose-dependent way. Arch Oral Biol 2010; 55: 185-94

8. Kanakamendala A, Geetha A, Uma S, Rajaram V, Tyagarajan R, Pamela E. Treatment of a furcation defect with PRF and bone graft. ENDO 2009; 3(2):127-35.

9. Dohan DM, Joseph C, Antoine, Steve LD, Anthony JJD, Jaafar M, et al. Platelet-rich fibrin (PRF): A secondgeneration platelet concentrate. Part I: Technological concepts and evolution. Oral Surg Oral Med Oral Pathol Oral Radiol Endod 2006; 101:E37-44.

10. Jia-Hui Fu, Chuan-Yi Su, Hom-Lay Wang. Esthetic soft tissue management for teeth and implants. J Evid Base Dent Pract 2012:S1: [129-142].

11. Choukroun J, Antoine D, Alain S, Marie-Odile G, Christian S, Dohan SL,et. al. Platelet-rich fibrin (PRF): A second-generation platelet concentrate. Part IV: Clinical effects on tissue healing. Oral Surg Oral Med Oral Pathol Oral Radiol Endod 2006;101:E56-60

12. Sato N. Guided tissue regeneration: periodontics and restorative maintenance a clinical atlas. New Malden Surrey: Quinstessence Publishing Co Inc; 2009. 159-95.

13. Jankovic S, Zoran A, Perry K, Vojislav L, Bozidar D, E. Barrie K, et.al. Use of platelet-rich fibrin membrane following treatment of gingival recession:a randomized clinical trial. Int J Periodont Restor Dent 2012;32:e41-e50.

14. Dohan DM, Choukroun J, Diss A, Dohan SL, Dohan AJJ, Mouhyi J, et. al. Platelet-rich fibrin (PRF): A secondgeneration platelet concentrate. Part II: Platelet-related biologic features. Oral Surg Oral Med Oral Pathol Oral Radiol Endod 2006;101:E45-50

15. Dohan DM, Choukroun J, Diss A, Dohan SL, Dohan AJJ, Mouhyi J, et al. Platelet-rich fibrin (PRF): A secondgeneration platelet concentrate. Part III: Leucocyte activation: A new feature for platelet concentrates? Oral Surg Oral Med Oral Pathol Oral Radiol Endod 2006;101:E51-5

16. Choukroun J, Diss A, Simonpieri A, Girard MO, Schoeffler C, Dohan SL, et. al. Platelet-rich fibrin (PRF): A second-generation platelet concentrate. Part V: Histologic evaluations of PRF effects on bone allograft maturation in sinus lift. Oral Surg Oral Med Oral Pathol Oral Radiol Endod 2006;101:299-30. 